\title{
SPECIES COMPOSITION AND SUSCEPTIBILITY TO ANTIBIOTICS OF MICROORGANISMS ISOLATED FROM TOOTH SOCKETS OF EXTRACTED TEETH IN CASES OF ALVEOLAR OSTEITIS
}

\author{
V.O. Malanchuk ${ }^{1}$, A. Javadiasl ${ }^{1}$, A.V. Rybachuk ${ }^{1}$, \\ M.V. Oblap ${ }^{1}$, V.V. Potochilova ${ }^{2}$ \\ ${ }^{1}$ Bogomolets national medical university, \\ 1 Zoologichna str, 03057, Ukraine \\ ${ }^{2}$ Kyiv Regional Clinical Hospital, \\ 1 Baggovutivska Str., Kyiv, 04106, Ukraine \\ e-mail:afshin.javadi@gmail.com
}

\begin{abstract}
Alveolar osteitis (AO) is one of the most common infectious complications after dental extractions. The data on the species composition of AO pathogens and their susceptibility to antimicrobial drugs can be the basis for their empirical use in case of inflammatory process aggravation. Objective. To determine the species composition and susceptibility to the antimicrobial agents of microorganisms, which were detected in patients with $A O$, who sought medical help in the oral surgery department of the dental medical center of Bogomolets National Medical University. Methods. Throughout 2018-2021, microbiological examination of tooth sockets from 30 patients with $A O$ and 20 patients without $A O$ was performed. The studied biological material was plated on appropriate nutrient media for isolation of aerobic, facultative and obligate-anaerobic microorganisms. Anaerobic conditions were achieved in GENbox 7.0 L and GENbox 2.5 L aerostats using GENbox anaerobic packages ("Biomerieux", France). The genus and species identity of the bacteria were determined according to Bergey. Antibiotic susceptibility of the isolated strains was determined by disk diffusion method. Results. It was found that most commonly microorganisms from tooth sockets in case of AO are: Staphylococcus aureus, Staphylococcus epidermidis, Streptococcus spp., Escherichia coli, Bacteroides spp., Clostridium spp., and Candida species, as well as their mixed cultures of 3-5 species of microorganisms. These aerobic and facultative anaerobic bacteria were susceptible to amoxicillin, ceftriaxone and ciprofloxacin in 92.6-100\% of cases. The growth of anaerobic bacteria in $100 \%$ of cases was inhibited by colistin and meropenem. Conclusions. AO developing is caused by pathological colonization of socket of the extracted tooth by representatives of endogenous microbiota, namely Staphylococcus aureus, Staphylococcus epidermidis, Streptococcus spp., Escherichia coli, which are present mainly in the mixed cultures with Candida albicans. For empirical antibiotic therapy of complicated forms of $A O$, amoxicillin or ceftriaxone or ciprofloxacin in complex with colistin or meropenem should be used, since these drugs suppress the growth of 92.6-100\% of strains of aerobic, facultative and obligate anaerobic microorganisms, which are potential pathogens of the purulent forms of $A O$.
\end{abstract}

Keywords: alveolar osteitis, alveolar osteitis pathogens, complication after tooth extraction, susceptibility to antimicrobial drugs.

Among the inflammatory complications after tooth extraction one of the leading places is occupied by alveolar osteitis (inflammation of tooth socket) (AO), which divides into purulent and serous types. According to various authors, they develop in $15-45 \%$ of patients $[1,2,3,4]$. It has been proved that endogenous and exogenous microorganisms that colonize the mucous membrane of the oral cavity play an essential role in the development of AO [5]. According to various authors, these include Staphylococcus, Streptococcus, Enterococcus, Clostridium, Bacteroides as well as Escherichia coli [6]. Moreover, the above-mentioned microorganisms were seen, typically, in alliances, especially with Candida species.

It should be noted that the species composition of $\mathrm{AO}$ pathogen and their associations depends on the 
immunological resistance of patients, the presence of concomitant diseases of the nasopharynx, as well as periodontal diseases. Treatment of AO is based on the extensive use of local various antiseptic agents, broad spectrum antibiotics, biogenic materials with antimicrobial effect, etc. Thus, in oral and maxillofacial surgery, chlorhexidine, hexetidine, triclosan, antiseptics based on biologically active components of medicinal herbs, etc. are widely used for mouthwash in the complex of hygienic procedures of oral cavity.

Despite the significant number of scientific works devoted to the search of approaches to AO treatment, this problem is still relevant due to the different susceptibility to antiseptics and antibiotics of microorganisms and their associations, which colonize the alveolus and cause its ignition, in different patients.

Based on the above, the objective of work was to determine the species composition and susceptibility to antimicrobial agents of microorganisms that were isolated from patients with AO who obtained medical care in the surgical department of the dental medical center of Bogomolets National Medical University.

Materials and methods. Throughout 20182021, microbiological examination was performed on alveolar extractions of 50 patients between 18 and 40 years of age who obtained medical care at the Department of oral and maxillofacial surgery of dental medical center of Bogomolets National Medical University. The treatment included 30 patients who were diagnosed with $\mathrm{AO}$ two to three days after extraction of the tooth. 20 patients without AO formed a control group. The examined patients did not have diabetes. There were no pregnant women or patients undergoing steroid therapy. All surgical interventions were performed using anaesthetics containing vasoconstrictors.

The material for microbiological investigations was the socket substance, which was sterilely taken with a syringe and put into tubes with the thioglycolic medium, this medium was first heated in a water bath (regenerated) for 2030 seconds at $100{ }^{\circ} \mathrm{C}$, and then sharply cooled in a crystalline crust in order to prevent the medium from being enriched with atomic oxygen from the air. To reduce the diffusion of atmospheric oxygen, after adding biologic material the medium was covered with sterile Vaseline oil (ball thickness $1-1.5 \mathrm{~cm}$ ) and incubated at $37{ }^{\circ} \mathrm{C}$ for $48-72-$ 96 hours until visible growth of microorganisms in the sample. For the isolation of obligate anaerobic microorganisms, the suspension was incubated in $5 \%$ blood agar, chocolate agar with Poly ViteX, Schiedler's broth with vitamin K3, Schiedler's agar with $5 \%$ sheep's blood. The biological material was plated by the sector method according to Gold and cultured in anaerobic conditions at $37{ }^{\circ} \mathrm{C}$ for 48-96 $\mathrm{h}$ until the visible growth appeared on the agar surface. Identification of anaerobic organisms was performed according to the method [7]. Anaerobic conditions were achieved in GENbox 7.0 L and GENbox $2.5 \mathrm{~L}$ anaerostats using GENbox anaeropackages ("Biomerieux", France). Anaerobiosis control was performed using Anaer Indikator ("Biomerieux", France).

Selective nutrient medium was used to identify facultative anaerobic and aerobic microorganisms: $5 \%$ blood agar, chocolate agar, selective salt agar ("Biolife", Italy), heterococcus agar ("Biolife", Italy), Endo agar ("Biolife", Italy), Saburo agar ("Biolife", Italy).

For bacteria bioluminescence accumulation the material was added to the sucrose broth and from it every $24 \mathrm{~h}$, transferred according to the gold method, repeatedly cultured in the thermostat at $37^{\circ} \mathrm{C}$ in aerobic conditions for $24 \mathrm{~h}$. Some media, i.e., chocolate agar, blood agar and modified medium for isolation of anaerobic bacteria, were prepared according to the appropriate prescriptions. The genus and species identity of the bacteria were determined according to Bergey [8].

The susceptibility of the isolated strains to antibiotics was determined by disk diffusion method according to Bauer-Kirby [9] using commercial disks with antibiotics on MüllerHinton medium - for uninhibited microorganisms, on Müller-Hinton medium supplemented with $5 \%$ blood and $20 \mathrm{mg} / \mathrm{L}$ NAD. When evaluating the activity of antibiotics, the criteria of the disk manufacturer were used. Depending on the diameters of the zones of microorganism growth inhibition near the discs with antibiotics the strains were classified as susceptible, moderately resistant or resistant. Antibiotic disks and media were monitored using test cultures of reference strains of E. coli ATCC 25922, Staphylococcus aureus ATCC 25923, Pseudomonas aeruginosa ATCC 27853, Enterococcus faecalis ATCC 29212, which were received from the museum of living cultures of microorganisms of Zabolotny Institute of Microbiology and Virology of the NAS of Ukraine.

Results. It was found that from the socket of patients with AO mainly contain Staphylococcus aureus, Staphylococcus epidermidis, Streptococcus 
spp., Escherichia coli, Bacteroides spp., Clos tridium spp. in $90.0 \pm 5.5 ; 60.0 \pm 8.9 ; 53.3 \pm 9.1$; $46.7 \pm 9.1 ; 60.0 \pm 8.9 ; 56.7 \pm 9.0 \%$ of cases respectively (Table 1).

Candida species were isolated in 53.3土 $9.1 \%$ of patients with $\mathrm{AO}$, indicating a violation of their colonization resistance, as a result, it can be the development of an infectious process in the socket of the extracted teeth, the etiological factor of which is represented by the normal oral cavity microbiota.

The socket of the control group of patients in 45$75 \%$ of cases had representatives of endogenous microbiota - bacteria of the genus Staphylococcus, namely S. aureus and S. epidermidis, Streptococcus spp., especially $S$. salivarius, as well as Clostridium spp. and Veillonella spp. Other microorganisms including $C$. albicans were isolated only from 5.0 to $15.0 \%$ of patients.

Thus, in case of AO after tooth extractions the sockets are colonized mainly by facultative anaerobic microorganisms, which may indicate a possible etiological role of these microorganisms in the development of AO (Fig. 1).

It should be noted that these microorganisms in $100 \%$ of cases were isolated in association of 3 5 species. The most frequent were the associations of C. albicans with Streptococcus spp. and E. coli $(16.7 \pm 6.8 \%)$, S. aureus + Streptococcus spp. + C. albicans $(13.3 \pm 6.2 \%), S$. aureus + Bacteroides spp. + C. albicans $(10.0 \pm 5.5 \%)$, S. epidermidis + S. aureus + Streptococcus spp. + C. albicans $(10.0 \pm 5.5 \%)$, C. albicans + Clostridium spp. + S. aureus $(6.7 \pm 4.6 \%), S$. aureus $+E$. coli + Streptococcus spp. + Candida albicans (6.7 $\pm 4.6 \%)$, S. epidermidis + S. albicans + Streptococcus spp. + C. albicans $(6.7 \pm 4.6 \%)$. Other mixed cultures were isolated in no more than $29.9 \pm 8.4 \%$ of cases each (Table 2). Moreover, C. albicans strains were the most common mixed cultures in the group of patients with AO.

Control patients tooth sockets contained mixed cultures of S. epidermidis, S. salivarius, and Veillonella spp. (20.0土8.9\%), Streptococcus spp., Clostridium spp. and Corinebacterium spp. $(20.0 \pm 8.9 \%)$, S. aureus, S. epidermidis

Table 1

Species composition of microorganisms isolated from sockets of extracted teeth

\begin{tabular}{|l|c|c|}
\hline \multirow{2}{*}{ Microorganisms } & \multicolumn{2}{|c|}{ Sighting frequency, \% } \\
\cline { 2 - 3 } & $\begin{array}{c}\text { Patients with alveolar osteitis } \\
\mathrm{n}=30\end{array}$ & $\begin{array}{c}\text { Control group } \\
\mathrm{n}=20\end{array}$ \\
\hline Staphylococcus aureus & $90.0 \pm 5.5$ & $45.0 \pm 11.1$ \\
\hline Staphylococcus epidermidis & $60.0 \pm 8.9$ & $70.0 \pm 10.2$ \\
\hline Streptococcus spp. & $53.3 \pm 9.1$ & $75.0 \pm 9.7$ \\
\hline Streptococcus intermedius & $36.7 \pm 8.8$ & 0 \\
\hline Streptococcus salivarius & 0 & $25.0 \pm 9.7$ \\
\hline Peptostreptococcus spp. & $36.7 \pm 8.8$ & 0 \\
\hline Enterococcus faecium & $30.0 \pm 8.4$ & $10.0 \pm 6.7$ \\
\hline Escherichia coli & $46.7 \pm 9.1$ & $15.0 \pm 8.0$ \\
\hline Corinebacterium spp. & $33.3 \pm 8.6$ & $15.0 \pm 8.0$ \\
\hline Clostridium spp. & $56.7 \pm 9.0$ & $75.0 \pm 9.7$ \\
\hline Bacteroides spp. & $60.0 \pm 8.9$ & 0 \\
\hline Veillonella spp. & 0 & $70.0 \pm 10.2$ \\
\hline Haemophillus spp. & $16.7 \pm 6.8$ & $5.0 \pm 4.8$ \\
\hline Candida albicans & $53.3 \pm 9.1$ & $10.0 \pm 6.7$ \\
\hline
\end{tabular}

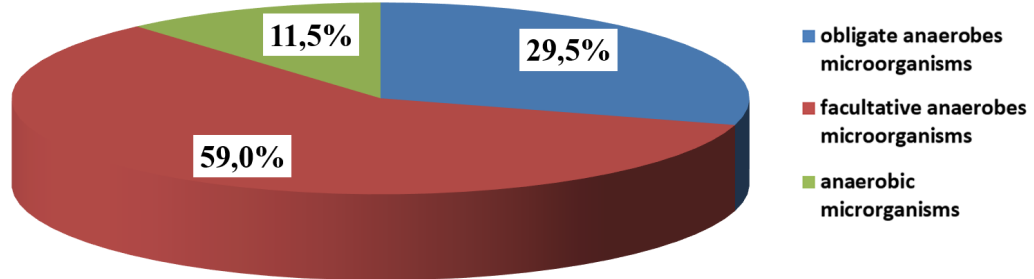

Fig. 1. Distribution of bacteria species associated with $\mathrm{AO}$ into physiological groups according to their relation to oxygen 
Table 2

Microbial mixed cultures of microorganisms isolated from socket of extracted teeth of patients with alveolar osteitis

\begin{tabular}{|l|c|c|}
\hline No. & Mixed cultures & Frequency \\
\hline 1 & C. albicans + Streptococcus spp. + E. coli & $16.7 \pm 6.8$ \\
\hline 2 & S. aureus + Streptococcus spp. + C. albicans & $13.3 \pm 6.2$ \\
\hline 3 & S. aureus + Bacteroides spp. + C. albicans & $10 \pm 5.5$ \\
\hline 4 & C. albicans + Clostridium spp. + S. aureus & $10 \pm 5.5$ \\
\hline 5 & S. aureus + E. coli + Streptococcus spp. + C. albicans & $6.7 \pm 4.6$ \\
\hline 6 & E. coli + S. intermedius + E. faecium + Clostridium spp. + S. epidermidis & $6.7 \pm 4.6$ \\
\hline 7 & S. epidermidis + S. aureus + Streptococcus spp. + C. albicans & $6.7 \pm 4.6$ \\
\hline 8 & Other & $29.9 \pm 8.4$ \\
\hline
\end{tabular}

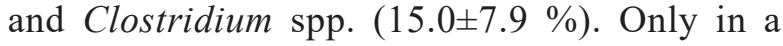
few cases different mixed cultures of 2 to 3 species of microorganisms with $C$. albicans or Enterobacteriaceae in their composition were isolated.

Since the dominant microorganisms that were isolated from the tooth socket of patients with $\mathrm{AO}$ were Staphylococcus spp., E. coli and Streptococcus spp., as well as unregulated anaerobic bacteria, we investigated their susceptibility to antibiotics that can be used in the treatment of AO.

As a result of these studies, amoxicillin, ceftriaxone and ciprofloxacin were the most active antibiotics that inhibited the growth of over $90 \%$ of $S$. aureus, $S$. epidermidis and E. coli strains (Table 3).

Ampicillin inhibited the growth of only 11.1$16.7 \%$ of the strains of these microorganisms. Tetracycline was most active against $74.1 \%$ of $S$. aureus strains and only $57.1 \%$ of $E$. coli strains.

As for Streptococcus bacteria, both Streptococcus spp., and $S$. intermedius were the most susceptible to amoxicillin, clindamycin, and ciprofloxacin, which inhibited growth from $81.3 \pm 9.7$ to $90.9 \pm 8.7 \%$ of the tested strains of these microorganisms (Fig. 2). Ceftriaxone was active against $75.0 \pm 10.8 \%$ of Streptococcus spp. strains and $81.8 \pm 11.6 \%$ of $S$. epidermidis strains. Cefazolin and tetracycline were the most active

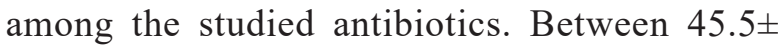
$15.0 \%$ and $63.6 \pm 12.0 \%$ of Streptococcus strains isolated from tooth sockets of patients with AO were susceptible to these drugs.

Bacterial isolates were the most susceptible to colistin and meropenem, which inhibited the growth of all the studied strains of Clostridium spp. and Basteorides spp. (Table 4). Clindamycin was active against $88.2 \pm 7.8 \%$ of the strains of Clostridium spp. and $94.4 \pm 5.4 \%$ of the strains of Bacteroides spp. Other antibiotics inhibited the growth of $55.6-66.7 \%$ of the strains studied.

It should be noted that we have not found any strains of microorganisms with multiple resistance to antibiotics, which confirms endogenous origin of AO pathogens in the examined patients.

\section{Table 3}

Susceptibility to antimicrobial agents of $S$. aureus, $S$. epidermidis, and $E$. coli strains isolated from patients with alveolar osteitis

\begin{tabular}{|l|c|c|c|}
\hline \multirow{2}{*}{ Antibiotic } & \multicolumn{3}{|c|}{ Number of susceptible strains (\%) } \\
\cline { 2 - 4 } & $\begin{array}{c}\text { S. aureus } \\
\mathrm{n}=27\end{array}$ & $\begin{array}{c}\text { S. epidermidis } \\
\mathrm{n}=18\end{array}$ & $\begin{array}{c}\text { E. coli } \\
\mathrm{n}=14\end{array}$ \\
\hline Ampicillin & $11.1 \pm 6.0$ & $16.7 \pm 8.8$ & $14.3 \pm 9.4$ \\
\hline Amoxicillin & $96.3 \pm 5.1$ & 100 & $85.7 \pm 9.4$ \\
\hline Cefazolin & $74.1 \pm 8.4$ & $66.7 \pm 11.1$ & $71.4 \pm 12.1$ \\
\hline Ceftriaxone & $92.6 \pm 5.0$ & 100 & 100 \\
\hline Gentamicin & $81.5 \pm 7.4$ & $83.3 \pm 8.8$ & $85.7 \pm 9.4$ \\
\hline Clindamycin & 100 & 100 & 0 \\
\hline Tetracycline & $74.1 \pm 8.4$ & $66.7 \pm 11.1$ & $57.1 \pm 13.2$ \\
\hline Ciprofloxacin & $96.3 \pm 5.1$ & $88.9 \pm 7.4$ & $92.9 \pm 6.9$ \\
\hline
\end{tabular}




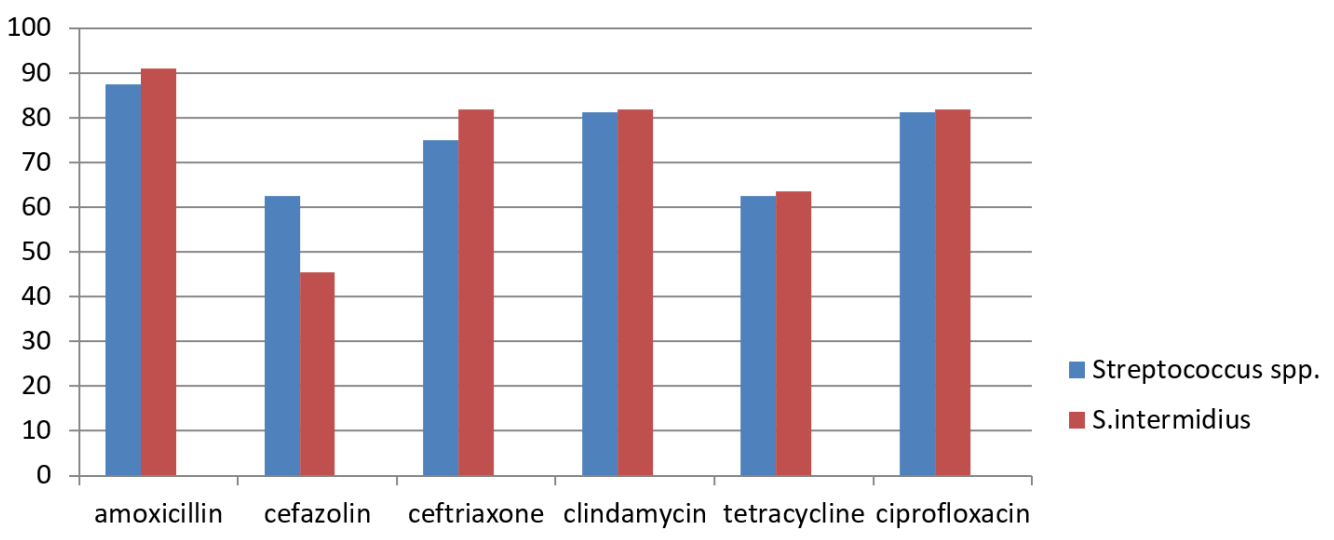

Fig. 2. Susceptibility to antibiotics of Streptococcus bacteria strains seen in patients with AO

Table 4

Susceptibility to antimicrobial agents of obligate anaerobes strains detected in patients with alveolar osteitis

\begin{tabular}{|l|c|c|}
\hline \multirow{3}{*}{ Antibiotic } & \multicolumn{2}{|c|}{ Number of susceptible strains (\%) } \\
\cline { 2 - 3 } & $\begin{array}{c}\text { Clostridium spp. } \\
\mathrm{n}=17\end{array}$ & $\begin{array}{c}\text { Bacteroides spp. } \\
\mathrm{n}=18\end{array}$ \\
\hline Metronidazole & $58.8 \pm 11.9$ & $66.7 \pm 11.1$ \\
\hline Ampicillin & $58.8 \pm 11.9$ & $55.6 \pm 11.7$ \\
\hline Clindamycin & $88.2 \pm 7.8$ & $94.4 \pm 5.4$ \\
\hline Imipenem & $58.8 \pm 11.9$ & $55.6 \pm 11.7$ \\
\hline Colistin & 100 & 100 \\
\hline Meropenem & 100 & 100 \\
\hline
\end{tabular}

Discussion. Today, despite the introduction of modern methods of prevention and treatment of inflammation which can occur after tooth extraction, serous and purulent $\mathrm{AO}$ remain a serious problem of oral and maxillofacial surgery. According to various authors, $\mathrm{AO}$ can comprise from 2.8 to $35 \%$ of complications after extraction of teeth $[10,11]$. The development of $\mathrm{AO}$ is influenced by a significant number of factors such as patient age, presence of somatic and infectious diseases, prolonged and complicated surgical treatment, patient's failure to follow the postoperative regimen, presence of prolonged postextraction bleeding, presence of a clot in the socket due to the use of disinfectants or its elimination, disregard of a doctor's recommendations (smoking, mouthwash after the surgery, alcohol consumption), etc. [12-17]. However, a special place belongs to AO. Microorganisms penetrate into socket from odontogenic infectious sources, as well as from nasal and nasopharyngeal cavities. Infections in the socket when the tooth is extracted due to acute or chronic periodontitis or exacerbation of periodontitis can also be the cause [11].
There are different approaches to AO treatment. These include the use of antimicrobial drugs injected directly into the socket of the extracted tooth, the use of low-intensity laser impregnation, the use of osteoplastic preparations, drugs that stimulate immunological reactivity of the body, etc. [12].

However, if local treatment is ineffective, severe complications such as chronic osteomyelitis can develop. In these cases, there is a need for parenteral or intravenous administration of broadspectrum antibiotics. In this case, it is necessary to take into account the data on the species composition of AO pathogens, as well as their susceptibility to antibiotics. This approach is based on the fact that through a wide and often irrational use of antibiotics, the species composition of the progenitors of infectious diseases tends to change and their level of antibiotic resistance tends to increase. This trend applies to oral cavity microbiota as well.

The data on the species composition of microorganisms that colonize tooth socket are contradictory. Thus, Borodulina I.I. and co-workers 
showed that 2 to 5 species of microorganisms were found in socket of patients with AO [11]. In this case, mainly C. albicans, S. saprophyticus, Enterococcus were identified from biological material. Other investigators showed prevalence of Streptococcus spp. (over $70 \%$ ), Actinomyces spp. (24.3\%), Peptostreptococcus spp. (15.98\%), Escherichia coli (16.23\%), Bacteroides spp. (6.81\%), and Candida spp. (8.9\%) [12].

The results of our research showed that the tooth socket of patients with $\mathrm{AO}$ are colonized mainly by endogenous oral microflora, namely S. aureus, S. epidermidis, Streptococcus spp. and E. coli. However, unlike other authors, a significant increase in the number of isolated anaerobic bacteria, namely Bacteroides spp., Clostridium spp. as well as $C$. aliphilus was identified. These microorganisms were seen as mixed cultures of 3-5 species of microorganisms, which included C. albicans strains, while in patients without AO, mixed cultures of 2-3 species of normal oral microbiota were isolated from tooth socket. This indicates that $\mathrm{AO}$ develops amid disruption of the quantitative and qualitative composition of the oral cavity microbiota, which can realize its pathogenic potential and cause inflammation of the pit of the extracted tooth. Thus, the data obtained indicate a possible etiological role of endogenous microbiota in the development of AO, as well as confirm the presence of oral cavity dysbiosis in patients with this pathology.

The treatment strategy for AO includes the mandatory use of antimicrobial drugs. The choice of drugs is often based on the physician's subjective assessment of the clinical picture and depends on his qualification. There are a lot of recommendations for treatment of AO. Some authors recommend using a combined method of AO treatment using Gramicidin C, prednisolone, benzocaine and low-intensity laser imaging, which allows to relieve pain syndrome and achieve significant antibacterial effect [10]. Others describe the use of various antibacterial drugs in combination with osteoplastic materials [18-21]. Therefore, the data on the leading pathogens of $\mathrm{AO}$ as well as their susceptibility to antibiotics and antiseptics are important for the selection of drugs for their extensive use. To determine the list of antimicrobial drugs that can be used, first of all for the treatment of patients with complicated forms of AO, for which not only local application of antiseptics is indicated, as well as parenteral administration of antibiotics, we determined the susceptibility of dominant pathogens of $\mathrm{AO}$ to antibiotics that are used in dentistry.

It was found that the microorganism strains studied did not have multiple resistance to antibiotics, which confirms their endogenous origin. Amoxicillin, gentamicin, ceftriaxone, and ciprofloxacin were the most active against $S$. aureus, $S$. epidermidis, and E. coli. In relation to strains of Clostridium spp. and Bacteroides spp. - colistin and meropenem, which inhibited the growth of all these microorganisms studied. Amoxicillin, clindamycin and ciprofloxacin were the most active against Streptococcus bacteria, inhibiting the growth of 81.3 to $90.9 \%$ of the strains of these microorganisms studied.

\section{Conclusions}

1. AO is associated with pathological colonization of extracted tooth's socket by representatives of endogenous microbiota, namely $S$. aureus, S. epidermidis, Streptococcus spp., E. coli, which were identified mainly in the mixed cultures with C. albicans.

2. For empirical antibiotic therapy of complicated forms of AO amoxicillin or ceftriaxone or ciprofloxacin in complex with colistin or meropenem can be used, since these drugs inhibit the growth of about $90 \%$ of the isolated strains of aerobic, facultative and obligate anaerobic microorganisms, which are most often isolated from tooth sockets of patients with $\mathrm{AO}$ and are potential pathogens of its purulent forms.

\section{ВИДОВИЙ СКЛАД І ЧУТЛИВІСТЬ ДО АНТИМІКРОБНИХ ПРЕПАРАТІВ МІКРООРГАНІЗМІВ, ВИДІЛЕНИХ 3 АЛЬВЕОЛ ВИДАЛЕНИХ ЗУБІВ ПРИ АЛЬВЕОЛІТАХ}

\section{В.О. Маланчук', А. Дэсавадіасл ${ }^{1}$, А.В.Рибачук', М.В. Облап ${ }^{1}$, В.В. Поточилова ${ }^{2}$}

${ }^{1}$ Національний медичний університет імені О.О. Богомольия, проспект Перемоги, 34, Київ, 01601, Украӥна

${ }^{2}$ Київська обласна клінічна лікарня, вул. Багговутівська, 1, Київ, 04106, Украӥна

$$
\text { Резюме }
$$

Серед інфекційних ускладнень після видалення зубів одне з провідних місць посідають альвеоліти. Дані щодо видового складу збудників альвеолітів та їх чутливості до антимікробних препаратів 
можуть стати основою для емпіричного використання останніх при загостренні запального процесу. Мета. Встановити видовий склад і чутливість до антимікробних препаратів мікроорганізмів, що виділялись у хворих альвеолітом, які звертались за медичною допомогою в хірургічне відділення Стоматологічного медичного центру НМУ імені О.О. Богомольця. Методи. Протягом 2018-2021 pp. мікробіологічно досліджено виділення з альвеол 30 пацієнтів із альвеолітом і 20 пацієнтів без альвеоліту. Досліджуваний біологічний матеріал засівали на відповідні поживні середовища для виділення аеробних, факультативно- та облігатно-анаеробних мікроорганізмів. Умови анаеробіозу досягали в анаеростатах GENbox 7,0 L та GENbox 2,5 L за допомогою анаеропакетів GENbox anaer («Biomerieux», Франція). Родову i видову належність виділених бактерій визначали за Bergey. Чутливість виділених штамів до антибіотиків визначали диско-дифузійним методом. Peзультати. Встановлено, що при альвеолітах із альвеол зубів виділяються переважно Staphylococcus aureus, Staphylococcus epidermidis, Streptococcus spp., Escherichia coli, Bacteroides spp., Clostridium spp., дріжджоподібні гриби роду Candida, а також

1. Dym H, Orrett EO. Oral surgery for the general dentist, an issue of dental clinics. Elsevier Health Sciences. 2011; 56(1):82.

2. Poeschl PW, Eckel D, Poeschl E. Prophylactic antibiotic treatment in third molar surgery - a necessity. J. Oral Maxillofac Surg. 2004; 62(1):3-8.

3. Bragger U, Schild U, Lang NP. Radiographic parameters. J Clin Periodontol. 1994; 21(6):42230.

4. Noroozi AR, Philbert RF. Modern concepts in understanding and management of the "dry socket" syndrome: comprehensive review of the literature. Oral surgery, oral medicine, oral pathology, oral radiology, and endodontics. 2009; 107(1):30-5.

5. Fernandes GJ, Hatton MN. Prevention of Alveolar Osteitis: A Case Report and Review of Literature. Journal of the Michigan Dental Association. 2017; 82(1):21-5.

6. Noneva NO. [Rationale for the use of new antiseptic agents for the prevention and treatment of alveolar osteitis, candidate dissertation]. 2009:44. Russian. їх мікст-культури з 3-5 видів мікроорганізмів. Ці аеробні та факультативно-анаеробні бактерії були чутливими до амоксицилін/клавуланової кислоти, цефтріаксону і ципрофлоксацину у 92,6-100% випадків. Ріст облігатно-анаеробних бактерій у 100 \% випадків пригнічувався колістином і меропенемом. Висновки. Альвеоліти розвиваються на тлі патологічної колонізації альвеол видаленого зуба представниками індигенної мікробіоти, а саме: Staphylococcus aureus, Staphylococcus epidermidis, Streptococcus spp., Escherichia coli, що виділяються переважно у складі мікст-культур з Candida albicans. Для емпіричної антибіотикотерапії ускладнених форм альвеолітів слід використовувати амоксицилін/клавуланову кислоту або цефтріаксон, або ципрофлоксацин у комплексі 3 колістином або меропенемом, оскільки зазначені препарати пригнічують ріст 92,6-100% штамів аеробних, факультативно- і облігатно-анаеробних мікроорганізмів, що є потенційними збудниками гнійних форм альвеолітів.

Ключові слова: альвеоліти, збудники альвеолітів, ускладнення після видалення зубів, чутливість до антимікробних препаратів.

7. Potochilova V, Samarin D, Yukhimenko O. [Method of isolation of anaerobic pathogens from cranial cavity in patients with acute necrotizing pancreatitis]. Patent of Ukraine 128512, № u 2018 020236; statement 05.03.2018; published: 25.09.2019, ballot № 18. Ukrainian.

8. Bergey's Manual of Systematic BacteriologySpringer-Verlag: New York; 2012. 2083 p.

9. Kirby-Bauer disk diffusion susceptibility test protocol. American Society for Microbiology (ASM), Washington, DC, USA; 2009. P.2

10. Kulaeva E. [Treatment of alveolar osteitis using low-intensity laser radiation and modern pharmacological agents] [dissertation]. Tver: Tver state medical university; 2019. Russian.

11. Borodulina I, Lantsova ES, Zheleznova EA, Solovyeva TL. [Microbiocenosis of a tooth socket in the development of alveolar osteitis]. Medico-pharmaceutical journal Pulase. 2008; 4:614. Russian.

12. Belanov GN. [Comprehensive treatment of patients with alveolitis using biogenic materials with antimicrobial effects] [dissertation]. Sama- 
ra: Samara state medical university; 2009. Russian.

13. Torres-Lagares D, Serrera-Figallo MA, Romero- $\mathrm{Ru}^{\prime} 1 \mathrm{z} \mathrm{MM}$, Infante-Cossío P, García-Calderón M, Gutiérrez-Pérez JL. Update on dry socket: a review of the literature. Medicina Oral, Patologia Oral y Cirugia Bucal. 2005; 10(1):77-85.

14. Tarasenko IV, Volozhin AI, Barer GM, Tarasenko SV, Tsarev VN, Zuyrjv YA, et al. [Experimental justification and clinical application of ER, CR: YSGG laser in the complex treatment of chronic generalized periodontitis]. Russian stomatological journal. 2009; 1:15-8. Russian.

15. Yaromenko AI. [Some aspects of etiotropic therapy of infectious and inflammatory diseases of the maxillofacial region in elderly and old people]. In: Thesis of $5^{\text {th }}$ international conference maxillofacial surgeons and dentists; 2000 May 21-22, Saint Petersburg, Russia. 2000. p. 208-9. Russian.

16. Hedstrom L, Sjogren P. Effect estimates and methodological quality of randomized controlled trials about prevention of alveolar osteitis following tooth extraction: a systematic review. Oral Surg Oral Med Oral Pathol Oral Radiol Endodont. 2007; 103(1):8-15.

17. Freudenthal N, SternuddM, Jansson L, Wannfors K. A double-blind randomized study eval- uating the effect of intra-alveolar chlorhexidine gel on alveolar osteitis after removal of mandibular third molars. J Oral Maxillofac Surg. 2015; 73:600-5.

18. Sokolova EA, Sherbovskikh AE. Treatment of alveolar osteitis with osteoplastic materials taking into account the spectrum of antibacterial activity of antiseptic drugs. Student Science and Medicine of the XXI Century: Traditions, Innovations and Priorities. 2010:299-300.

19. Nathani DB, Sequeira J, Sripathi Rao BH. Comparison of platelet rich plasma and synthetic graft material for bone regeneration after third molar extraction. Annals of maxillofacial surgery. 2015; 5(2):213.

20. Dutta SR, Passi D, Singh P,Sharma S, Mahinder Singh, Srivastava D. A randomized comparative prospective study of platelet-rich plasma, platelet-rich fibrin, and hydroxyapatite as a graft material for mandibular third molar extraction socket healing. National journal of maxillofacial surgery. 2016; 7(1):45.

21. Nebu GT, Sanil GP, Rajmohan G, Prabhakaran JV, Panda AK. Fabrication and anti-microbial evaluation of drug loaded polylactide space filler intended for ridge preservation following tooth extraction. Journal of Indian Society of Periodontology. 2011; 15(3):260.

Received 8.10.2021 